\title{
Treatment of Older People in Tanzania: A Brief Look at the Law and Practice
}

\author{
ABDLILRAHMAN O.J. KANIKI \\ Part-Time Lecturer in Law, Faculty of Law \\ The Open University of Tanzania
}

\begin{abstract}
This article examines, albeit briefly, the treatment of older people in Tanzania. It seeks to look at the law and practice regarding the status accorded and protection provided to this part of the population. It can hardly be disputed that older people have contributed immeasurably to the country's present state and that their working capacities are either exhausted or greatly reduced. In this understanding therefore, how far the state is mindful towards providing protection and maintaining the welfare and well-being of these senior citizens, is among the pertinent issues the article attempts to address.
\end{abstract}

\section{INTRODUCTION}

Tanzania, as is the case with other countries in the world, is witnessing a steady increase in number of older people. This is in realisation that the entire population is on the increase. It has been argued that: "The world is experiencing a steady increase in the number of elderly people (defined here as the over-60s). In demographic terms, this group is the fastest growing section of the global population. According to United Nations statistics, the number of people over 60 rose by $63 \%$ between 1960 and 1980. Between 1955 and 2025 , it was predicted that this age group would quadruple in size. Already, more than half the world's elderly people live in developing countries and this proportion is set to rise to three-quarters by 2025. Lower infant motality rates, advances in medical care and improved living standards mean that those who survive childhood disease now stand an improved chance of living a longer life - no matter where they are no the planet." ${ }^{11}$

There is however, one pertinent question to be posed at this stage: Is Tanzania determined to ensure that her older people, who contributed immeasurably to her present state and whose working capacities are either exhausted or greatly reduced, are leading happier lives as opposed to miserable ones? In other words, does Tanzania have in place well defined socio-economic policies, which are aimed at ensuring the well-being of this important part of the population? In this connection therefore, are older people really in a position to celebrate this state of life? Has the country created conducive socioeconomic and legal environments which enable her senior citizens to cope with old age period?

May be some young, energetic, resourceful and self-reliant people could say it is too early for them to think of old age because the stage is far away. They should, however, bear in mind that hopefully, no sooner than later they will 
be some day senior citizens. Nobody has ever been born older. After all, so long as we are still alive we cannot escape ageing as a process which has to inevitably be undergone by us all. It is just a question of time.

\section{THE LAW AND PRACTICE: ARE OLDER PEOPLE AFFORDED ANY PROTECTION?}

It appears that the constitution ${ }^{2}$ considers that question of ageing. Whether the consideration is meaningful or not that is another thing. The constitution has some provisions talking of old age. Under article 11(1) it provides that: "The state authority shall make appropriate provisions for the realisation of a person's right to work, to self education and social welfare at times of old age, sickness or disability and in other cases of incapacity. Without prejudice to those rights, the state authority shall make provisions to ensure that every person earns his livelihood."

No one can deny a fact that the constitution of a state is the supreme law of the realm. It is a society's most important set of rules and values about how people should live, enforce and enjoy their fundamental rights, and the like. Moreover, all the formulated national policies whether political, social or economic must be compatible with the country's constitution. Going contrary will be to violate the constitution hence rendering it meaningless and irrelevant body to be found in a society.

In view of the above, even ordinary laws should be compatible with the constitution. That is to say they should be in line with what the constitution offers.

To comply with provisions of the constitution as quoted above particularly to realise social welfare of older people, the state has enacted a piece of legislation namely, the Disabled Persons (Care and Maintenance) Act, 1982. ${ }^{3}$ We so submit because among the persons covered by this piece of legislation are people with old age. It means that for the purposes of this law, older people are among the people qualifying to be called the disabled persons. Under section 2 the term "disable person" is defined to mean a person who, on account of injury, old age, disease or congenital deformity, is substantially handicapped in obtaining employment, or in undertaking work on his own account, of a kind which apart from that injury, old age, disease or deformity would be suited to his age, experience and qualification.

Reading from its long title, it is clear that this law, that is the Disable Persons (Care and Maintenance) Act 1982, is enacted in order to "...provide for the Care and Maintenance of disable persons and for purposes connected with those matters." One thus expects much from this law with respect to welfare of older people since they are among the beneficiaries of the law at issue. Put in other words, it is expected that the state would show its commitment to see that older people live happier as opposed to miserable life. 
A cursory look at contents of above-quoted article 11(1) of the Constitution and provisions of the Disable Persons (Care and Maintenance) Act 1982, hereinafter referred to as the Act for ease of reference, one would think that older people in Tanzania are adequately taken care of and maintained by the state.

However, a thorough reading of provisions of the Act makes us to comment that so far no much is expected from the state as far as welfare of older people is concerned. The Act never went beyond what has ever been the practice with respect to who has an obligation to take care of and maintain an older person prior to its inception. The reality is that long before the Act came into operation it has been and still is upon an older person himself or his relatives to look after him. The Act just reiterates same position when stating under section 14 as follows:

"14.-(1) Every relative of a disable person shall have an obligation to care and provide for the maintenance of that disable person, according to his means. (2) Where there are more than one relatives of a disable person; all the relatives shall have the obligation to care and to provide for the maintenance of the disabled person."

Under section 15 the court is empowered to order a relative who willfully neglects to provide reasonable care and maintenance to a disabled person to maintain such person.

May be for those readers who have happened to come across the Act would argue that it goes further to offer provisions which are to the extent of mandatorily ordering local authorities to provide facilities for the care and maintenance of disable persons, older people included, under section 16 which says: "16.-(1) Every local authority shall, either alone or in collaboration with any person or institution, establish, operate, manage and maintain facilities for the care and maintenance of person who are disable.

(2) A local authority shall provide for the care and maintenance of every disable person who has no relative who can provide for his care and maintenance and who is ordinarily resident in the area of its jurisdiction."

Some pertinent questions to be asked in connection with the provisions of section 16 quoted above are as follows: Has what is state under this section ever been implemented by local authorities in the country? Do we have local authorities which are really committed to take care and maintain old people in their respective jurisdiction? Can older people bring their respective local authorities before courts of law to compel them to take care of such people in case they "...willfully neglect to provide reasonable care and maintenance" as so is the case with relatives.? Is the Act having such provisions? The answer to all these questions is no. This shows how big the gap is between what is 
offered by law and what is existing in practice. All the same we may argue that what is offered by the law does not provide an adequate protection of older people socio-ecnomically.

\section{THE REAL LIFE LED BY MOST OF OLDER PEOPLE IN TANZANIA}

Older people in Tanzania are the most forgotten part of the entire population. As a result of this, a prevailing view points to the fact that the future of most older people in this country, as is the case with many developing countries, is not promising. A cursory survey may indicate that many of these people find old age akin to punishment. Theirs is miserable life. We say so because at this age they notice that the life they used to lead during the past when they were energetic is quite different from the one they are facing at this eleventh hour.

Take for example the case of those who were employees. Except for a very few of those who have saved well, much depending on the posts they used to hold, the rest fail to meet at least the minimum standard of living they led in the past. Facilities like medical care, transport services and the like are now unaffordable to them. Whereas at this stage they are more likely to suffer from several medical conditions associated with their age and which in many cases are poorly understood. In this connection therefore, they cannot escape medical stress as so explained by one South African medical expert, Professor Adrian O. Wilson of University of Cape Town, in the following words: "Wherever you are in the world, ageing will produce, to varying degrees, a mix of medical, mental, social and functional (physical) stresses. Medical stress is a result of multiple pathologies, reduced function of organs, too many drugs, and the fact that older people usually fail to present a typical picture of illness. One can add to this the facts that older people have less tolerance to physical stresses, and that there is more than a suspicion of indifference in prevailing medical attitudes towards them. It is then reasonable to surmise that the frail elderly (our most vulnerable) are at most risk, not only in the community, but also in hospital"

To reduce such stresses therefore, it would be suggested, there is a need for the whole community to support the older people morally and materially.

In case of rural dwellers, who constitute the majority of the Tanzania population, bitterness is also the story. Whereas in the past the bond uniting older people with members of their immediate and extended families as well as the community was so strong nowadays it has started weakening. While in those old days older people were taken care of and maintained by family and community members things have greatly changed presently. The position so far appears to be that in most cases if one did not have a number of "responsible" sons and daughters who have to inevitably take responsibility of taking care of him/her one has to look after oneself till the time of death. 
This is due to breakdown in family structures brought about by rapid urbanisation and economic hardships. Writing for the Courier, the Africa Caribbean - Pacific - European Union magazine, Ruth Evans goes into detail when arguing that: "Traditionally of course, Africa has respected its elderly, and large, extended families have provided guarantees for old age that would be the envy of many isolated and lonely pensioners in the Western world...

At the same time, in the absence of pensions and social security systems, children are viewed as security against old age. The more children you have, the more there will be to look after you in you twilight years and the more secure you hope to be...

With rapid urbanisation and difficult economic circumstances across the whole continent, many families now find it impossible to look after the elderly, even though they may want to. Extended family structures are breading down just at the point when the continent will need them most." 5

In view of the above the fact that one has to look after oneself one has thus to suffer living an isolated life till the time of death. As if this is not enough, older people living isolated lives are at the same time suspected of being witches and feared or hated for that $!^{\prime}$ Researchers reveal that Shinyanga killings on witchcraft beliefs have been mostly befalling such single and lonely older women. One such researchers, Kate Forrester Kibuga, a Tanzania - based freelance consultant specialising in social research, and participatory and gender issues, has the following to reveal being part of the findings:

"Belief in witchcraft is as old as society itself, but it has always been kept in check, in part by the councils of elders as the collective wisdom of older people. But nowadays, more and more older women are being accused of being witches, and such accusations often have grim consequences."7

The researcher continues to submit in this connection that:

"So why is there this alarming trend in some rural areas? One reason that has been suggested is that the circumstances and appearance of older women conspire against them. Nowadays, many more windows live alone than before, and if they are not seen much around the village, an air of mystery may grow up around them. They have no support to counter witchcraft accusations. They are weak, vulnerable and usually poor, so do not have the resources to fight. They may often have physical signs which influence those inclined to believe in witchcraft: for example, bloodshot eyes from cooking over a smoky fire all their lives, and the inescapable characteristics of old age anywhere (wrinkles, bags under the eyes, grey hair, twisted limbs and gnarled hands). ${ }^{8}$

HIV / AIDS epidemic has as well contributed greatly to the miserable life led by many of older people in the country. They are forced by circumstances to 
shoulder a burden of taking care of their children and young relatives when they are ill and bringing up their orphaned grandchildren. It has been argued by one Ruth Evans in this connection that: "...With so many of the continent's middle generations being wiped out, old people are left increasingly vulnerable. It is often the older generations that are left to look after children orphaned by the epidemic. Just at the time when these old people would otherwise have looked forward to being cared for themselves, they now find they have to take one the difficult and burdensome task of bring up and providing for-in some instances, numerous-grandchildren, some of whom may also be sick."

Similarly Fernando Goncalves observes in respect of the burden which has to be carried out by older people regarding HIV/AIDS orphanage in the following words: "...there is the fact that most of the dying are young parents who leave their orphaned children in the care of their frail, resourceless parents. Without the necessary resources to fend for their orphaned grand children, grand parents have to look elsewhere for assistance. Otherwise the grandchildren will have no money for adequate nutrition and school."10 That is the real life led by most of older people in Tanzania. It is in fact a miserable life these senior citizens are forced to encounter.

\section{GOVERNMENT TO BLAME}

One thing to be noted is that the government has contributed to the miserable life led by older people. There lacks well-defined and clear policies aimed at protecting older people. May by one may argue that there are such funds like the National Social Security Fund, Parastatal Pension Fund and the like. Well and good and fair enough for the targeted groups of people. But what about those who are not beneficiaries of such programmes? Whereas it is a reality that such funds normally serve a handful of members, does it mean that by having such funds whose efficacy is found mainly in urban centres the government is contented? What about the rural dwellers who constitute the majority of the Tanzania population?

Presently it is well settled that with the shrinking of the formal sector, the informal sector is expanding. This is an indication that the latter is about to absorb many job seekers including those who had been retrenched in the now privatised public enterprises. In this line of argument, how far the government of the day has created conducive environment of ensuring that those who involve themselves in the informal sector will live happier life as opposed to miserable one at the time of ageing?

\section{CHALLENGES TO POLICY MAKERS}

Perhaps it is high time that policy makers revisited the whole issue of life of our senior citizens. Let us see than in the near future we have policies which make provisions to enable every older person to enjoy such social facilities as 
health care, reliable transport, good housing, clean water, enough food and the like; either free of charge or at highly subsidised costs.

It is a reality that such people have contributed to the development of this country. Why such free social services are at most afforded to those who happened to have held high offices only? Are the rest of older Tanzanians not entitled to sharing the national cake whose making they had heavily and immeasurably contributed? Let policy makers take these questions as serious challenges to them.

\section{NOTES AND REFERENCES}

1. Morrissey, D., "An ageing world," The African - Caribbean - Pacific European Union Courier, No 176 - July - August 1999, p. 38.

2. That is the United Republic of Tanzania Constitution, 1977 as amended several times

3. Act No. 3/1982.

4. Wilson, A.O., "Targeted medical services for older African - a new imperative," The Courier, op cit., p. 46, pp. 46 - 47.

5. Evans, R., "Growing old in Africa," in The Courier, ibid., p. 40

6. Kanywanyi, J.L., "Informal Social Security Practices and their Underlying Norms and Principles - Old and New," Notes for a Panel Discussion on Social Security at the Social Welfare Institute Kijitonyama, $8^{\text {th }}$ March 1997, p. 5

7. Kibuga, K.F., "Wisdom and witchery," in The Courier, op cit., p. 66

8. Ibid., p. 67

9. Evans, R., op cit. See also Kaseke, E. "Social Security and the elderly: the African experience", in The Courier op cit $p .50$ who argues on page 52 that:

"The AIDS pandemic in Eastern and Southern Africa has worsened the problem of income insecurity among elderly people in that many of the latter are forced to take over the care of their grandchildren after the death of the parents. Those who die of AIDS - related illness seldom leave much, if anything, for their offspring. Grandparents have to use the limited resources at their disposal to support the children, thereby driving them deeper into poverty. There is no doubt that the elderly are now living very stressful lives."

10. Goncalves, F., HIV/AIDS in Africa: A continent Heading for dom?" In Southern African Political and Economic Monthly, Vol. 14 No. 7, 2001 p. 5 at p. 6. 